\title{
ADAR wt Allele
}

National Cancer Institute

\section{Source}

National Cancer Institute. ADAR wt Allele. NCI Thesaurus. Code C157284.

Human ADAR wild-type allele is located in the vicinity of $1 \mathrm{q} 21.3$ and is approximately 46 $\mathrm{kb}$ in length. This allele, which encodes double-stranded RNA-specific adenosine deaminase protein, is involved in ribonucleotide deamination. Mutations in the gene are associated with dyschromatosis symmetrica hereditaria and Aicardi-Goutieres syndrome type 6. 